\title{
A Case of Osteoblastoma Accompanied with Concha Bullosa of the Inferior Turbinate
}

\author{
Jung Suk Kim, Hyun Min Lee, Si Young Lee, and Ju Hee Han \\ Department of Otolaryngology, Presbyterian Medical Center, Jeonju, Korea
}

\section{수포성 갑개를 동반한 하비갑개의 골모세포종 1 예}

김정석 · 이현민 · 이시영 · 한주희

전주예수병원 이비인후과

\author{
Received July 27, 2016 \\ Revised September 13, 2016 \\ Accepted September 26, 2016 \\ Address for correspondence \\ Ju Hee Han, MD \\ Department of Otolaryngology, \\ Presbyterian Medical Center \\ 365 Seowon-ro, Wansan-gu, \\ Jeonju 54987, Korea \\ Tel $+82-63-230-1480$ \\ Fax $+82-63-230-8775$ \\ E-mail juhee.hn@gmail.com
}

Osteoblastoma is a rare benign tumor, representing less than $1 \%$ of all bone tumors. Most cases occur in the vertebrae and in the long bones. Intranasal or paranasal osteoblastoma is particularly rare and only one case of osteoblastoma in the inferior turbinate has been reported in the world literature. Treatment is intralesional curettage or en bloc resection. Since the tumor is benign, conservative surgery is curative in about $80-90 \%$ of the cases. Concha bullosa is an abnormal pneumatization of the intranasal turbinates and inferior concha bullosa is a very rare condition. We report an unusual case of osteoblastoma occurring together with inferior concha bullosa. The tumor and inferior concha bullosa were removed by endoscopic submucosal inferior turbinoplasty, with favorable results. Related articles are reviewed and brief discussions are presented in regards to the case findings.

Korean J Otorhinolaryngol-Head Neck Surg 2017;60(1):34-7

Key Words Concha bullosa $\cdot$ Inferior turbinate $\cdot$ Osteoblastoma.

\section{서 론}

골모세포종은 전체 골 종양의 $1 \%$ 이하에 해당하는 매우 드 문 양성 골 종양이다. 10 30세 사이에서 호발하며 성별 빈도 는 남자에서 여자보다 약 2 배 이상 높게 발생한다. 어느 골에 서나 발생할 수 있지만 주로 척추나 사지의 장관골, 편평골에 서 호발하고 두경부에 발생하는 경우는 드물다.

수포성 갑개는 비내갑개의 함기화로 주로 중비갑개에서 발 생하며 하비갑개에서 발생하는 경우는 매우 드문 변이로 보 고된 바가 드물다. ${ }^{2)}$

저자들은 하비갑개에서 골모세포종과 수포성 갑개가 동시 에 발견된 1예를 치험하여 이를 보고하는 바이다.

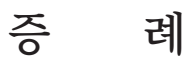

이미 알레르기 비염으로 진단되어 간헐적인 약물 치료를 했
던 9세 여아가 호전되지 않는 비폐색을 주소로 7개월 만에 다 시 내원하였다. 비강 진찰소견과 비내시경 검사상 이전에 보 이지 않았던 종물이 우측 하비갑개에서 발견되었다(Fig. 1). 이에 시행한 전산화단층촬영에서 우측 하비갑개의 전방부에 원형의 팽창성 병변이 관찰되었다(Fig. 2).

전신마취하에 내시경적으로 우측 하비갑개 전반부를 절제 하여 비교적 간단히 종괴를 제거할 수 있었으며, 제거한 병변 뒤쪽으로 부종성 점막으로 이루어진 빈 공간이 발견되었다 (Fig. 3). 이는 수포성 갑개 소견으로 전산화단층촬영상 팽창 성 병변 후방부에 내부가 균일한 저음영을 보이는 작은 골테 두리로 확인할 수 있었다(Fig. 2). 이에 미세흡입분쇄기로 하 비갑개의 외측 점막만 제거한 후 전벽 및 외측 골성 판을 제 거하는 하비갑개 성형술을 시행하였다. 종물의 병리소견은 불규칙한 골 소주와 그 주변을 둘러싸는 골모세포들이 관찰 되어 최종적으로 골모세포종으로 진단되었다(Fig. 4). 수술 후 비폐색은 해소되었으며 4주째 시행한 비내시경 소견상 종 
양의 재발이나 합병증은 없었다.

\section{고 찰}

골모세포종은 1956년 Jaffe와 Lichtenstein에 의해 처음으 로 기술된 양성 골형성 종양으로 비강 내에서 발견된 사례는

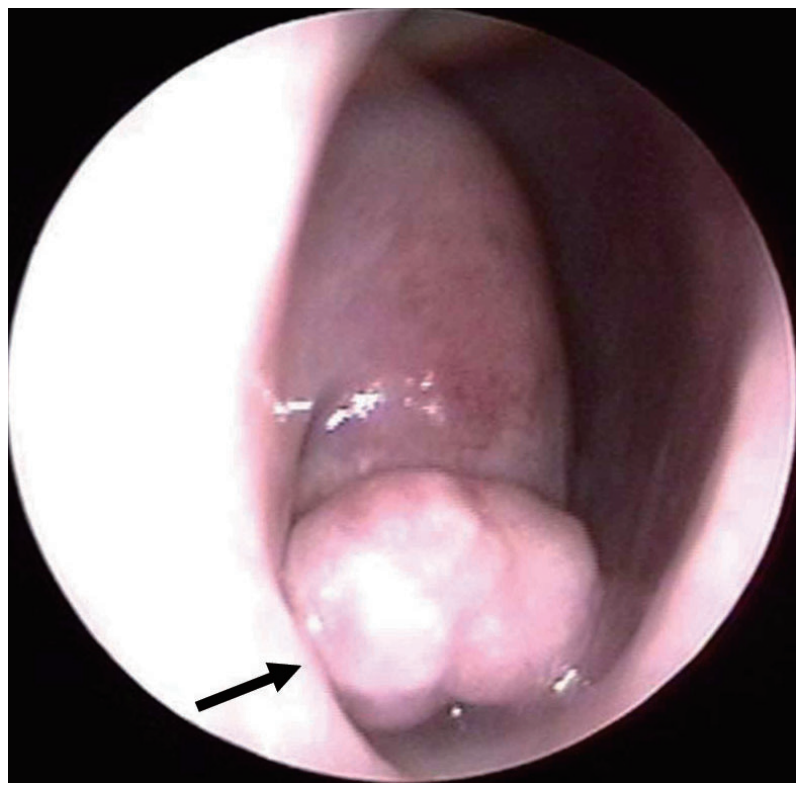

Fig. 1. Preoperative nasal endoscopic finding reveals a friable polypoid mass (arrow) from the right inferior turbinate.
Freedman과 Fu와 Perzin에 의해 1974년에 보고되었다. 비 강 내에서는 주로 사골동에서 발생하며 하비갑개에 발생한 경우는 전세계적으로 1예만 보고된 바 있다(Table 1).

대개 서서히 진행하기 때문에 진단을 의심할 만한 특징적인 증상은 보이지 않고, 주로 통증을 주소로 내원하게 된다. 통 증은 비특이적이고 야간에 통증이 심해지며 NSAID의 투여

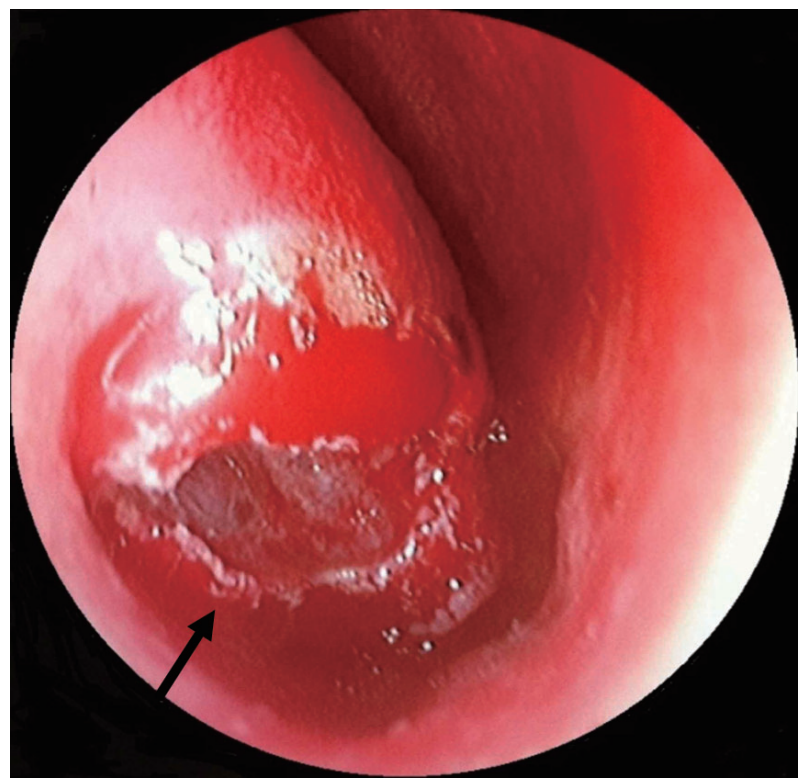

Fig. 3. Operative endoscopic photograph showing the air cell after removing the mass (arrow) from the right inferior turbinate.
Fig. 2. Preoperative nonenhanced axial $(A)$, sagittal $(C)$, and coronal $(B$ and D) CT scan shows a circumferential expansile lesion (arrow) and a small round bony rim (arrowhead) on the right inferior turbinate.
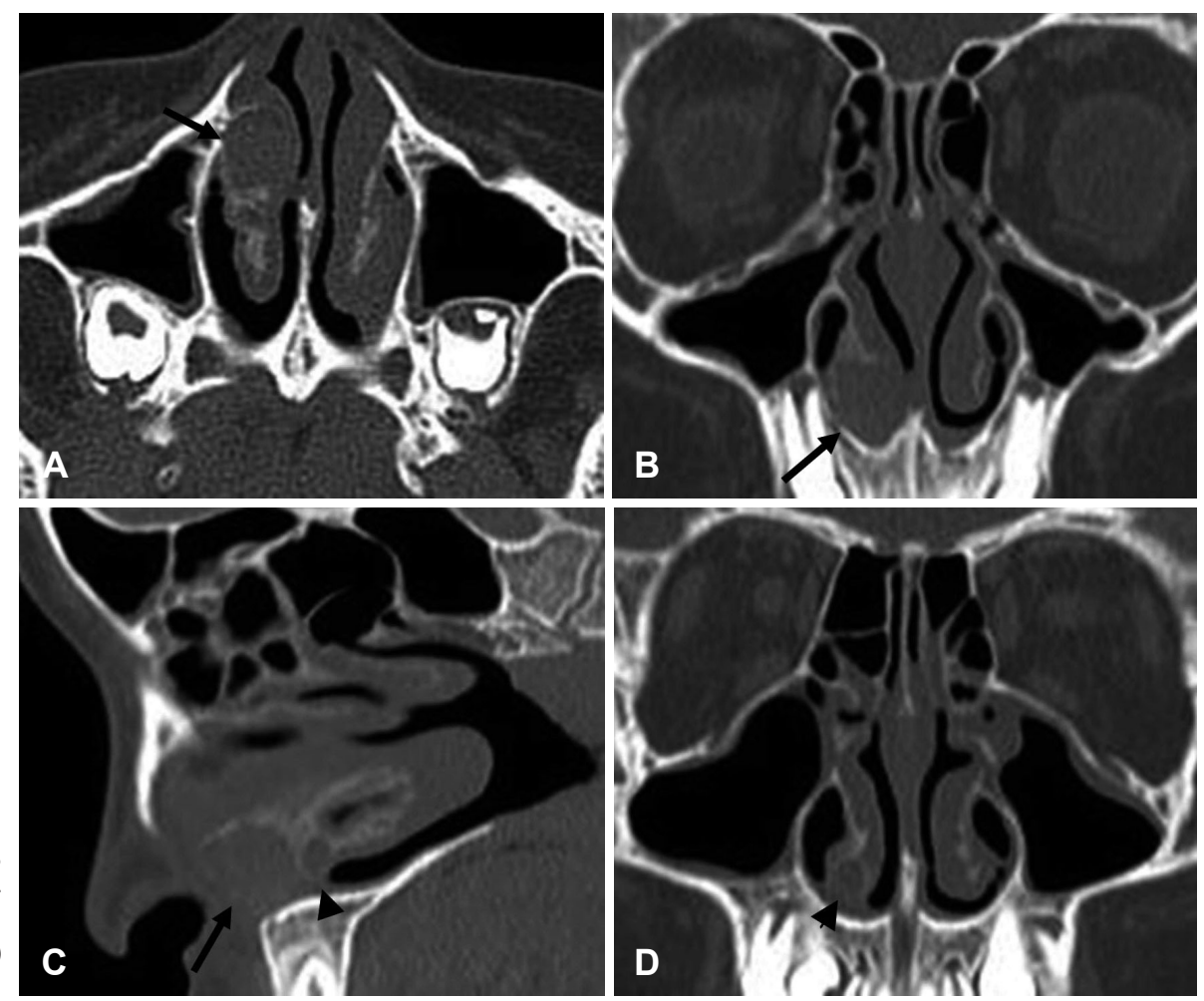
로 감소하기도 한다. 종양은 팽창성으로 성장하면서 압력에 의하여 인접한 골조직을 변형 또는 파괴시키기도 하며 신경 학적 이상이 나타날 수 있다. 특히 종양이 비강 내에서 발생 한 경우 팽창된 종양의 위치와 확장 정도에 따라 비폐색, 두 통, 복시, 유루, 안구돌출 등이 나타나며 뒤늦게 안각격리증 이 보이기도 한다(Table 1).

방사선학적으로 다양한 형태의 소견을 보여 척추 이외에서 발생한 경우 진단에 도움이 되는 특징적인 소견은 드물다. 단
순 방사선 사진상 석회화된 핵(nidus)과 주위를 둘러싸고 있 는 방사선 투과성 륜(halo)과 주위의 경화성 골이 관찰될 수 있지만, 대부분은 방사선 투과성, 경화성, 또는 이들이 혼합되 어 나타나기도 한다. ${ }^{3)}$ 전산화단층촬영은 가장 유용한 진단방 법이며 종양의 기원과 크기 및 윤곽을 쉽게 알 수 있다. 일반 적으로 인접한 뼈 구조물이 재형성된 팽창성 병변을 보이며 중심부는 고밀도의 석회화, 주변부는 연조직의 음영이 특징적 이다. 자기공명영상검사는 주위 연부조직의 소견이나 인접 골

Fig. 4. Pathologic findings of osteoblastoma; showing the presence of irregular trabeculae composed of woven bone and osteoid (black arrows) in a loose fibrovascular connective tissue stroma $(\mathrm{H} \& \mathrm{E}, \times 100)$ (A). Numerous osteoblasts encircle the osteoid (white arrows) and prominent stromal vascularity is noted in the osteoid tissue $(H \& E, \times 200)(B)$.
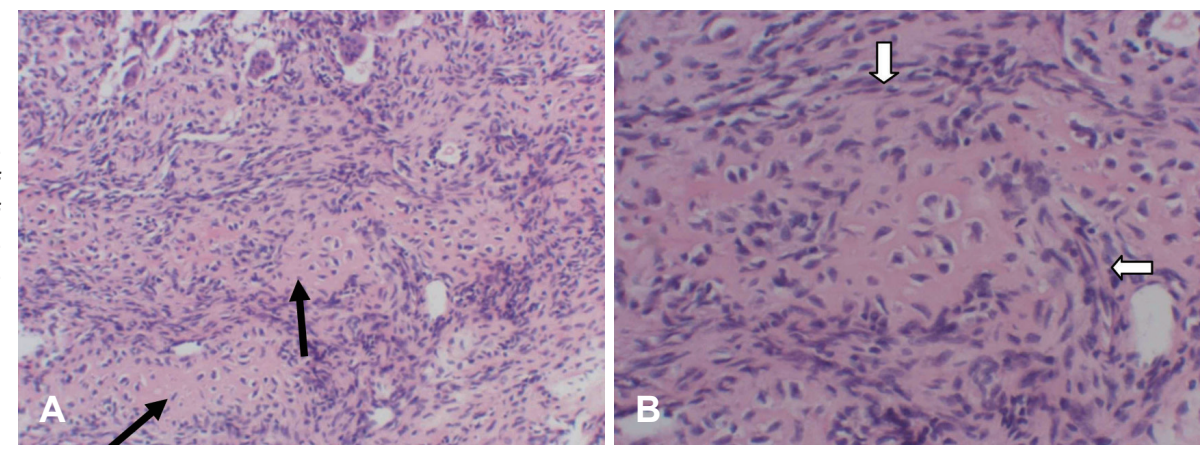

Table 1. Reported cases about osteoblastoma which occurred in the nasal cavity or paranasal sinuses (the following reference information was retrieved from the online data base of biomedical literatures published in the 2000s)

\begin{tabular}{|c|c|c|c|c|c|c|}
\hline Study & Age & Sex & Symptom & Origin & Treatment & Outcome \\
\hline Kukwa, et al. $\left.{ }^{1}\right)$ & 12 & $\mathrm{~F}$ & $\begin{array}{l}\text { Bilateral exophthalmos, } \\
\text { headache }\end{array}$ & $\begin{array}{l}\text { Posterior ethmoid \& } \\
\text { sphenoid sinus }\end{array}$ & $\begin{array}{l}\text { Bilateral fronto-orbital } \\
\text { craniotomy }\end{array}$ & $\begin{array}{l}\text { Recurrence after } \\
4 \text { months }\end{array}$ \\
\hline Jaswal, et al. ${ }^{3)}$ & 8 & $\mathrm{~F}$ & Facial deformity & Rt maxillary sinus & ESS with navigation & Not reported \\
\hline Young, et al. ${ }^{4)}$ & 45 & M & $\begin{array}{l}\text { Recurrent Rt epistaxis, } \\
\text { nasal obstruction }\end{array}$ & Nasal septum & Not reported & Not reported \\
\hline Chang, et al. ${ }^{5}$ & 35 & $\mathrm{~F}$ & Rt nasal obstruction & Rt inferior turbinate & $\begin{array}{l}\text { Wide surgical tumor } \\
\text { excision }\end{array}$ & $\begin{array}{l}\text { No recurrence after } \\
9 \text { months }\end{array}$ \\
\hline Cekic, et al. ${ }^{6)}$ & 40 & M & Lt superior gaze palsy & $\begin{array}{l}\text { Lt ethmoid \& frontal } \\
\text { sinus }\end{array}$ & Bifrontal craniotomy & Not reported \\
\hline Cikojević, et al. ${ }^{7)}$ & 14 & $M$ & $\begin{array}{l}\text { Rt nasal obstruction, } \\
\text { headache }\end{array}$ & Rt middle turbinate & $\begin{array}{r}\text { Endoscopic } \\
\text { technique }\end{array}$ & Not reported \\
\hline Kim, et al. ${ }^{8)}$ & 66 & M & $\begin{array}{l}\text { Lt epiphora, } \\
\text { exophthalmos }\end{array}$ & Lt ethmoid sinus & $\begin{array}{l}\text { Lt medial maxillectomy } \\
\text { via lateral rhinotomy }\end{array}$ & $\begin{array}{l}\text { No recurrence after } \\
6 \text { months }\end{array}$ \\
\hline Park, et al. ${ }^{9)}$ & 13 & M & Rt exophthalmos & Rt ethmoid sinus & Curettage \& drilling & $\begin{array}{l}\text { No recurrence after } \\
1 \text { year }\end{array}$ \\
\hline Sidani, et al..$^{10)}$ & 23 & M & $\begin{array}{l}\text { Lt blurred vision, } \\
\text { bilateral frontal } \\
\text { headache }\end{array}$ & Lt frontal sinus & Bicoronal craniotomy & Not reported \\
\hline Kavurt, et al. ${ }^{11)}$ & 11 & $\mathrm{~F}$ & $\begin{array}{l}\text { Swelling of the nasal } \\
\text { septum }\end{array}$ & Nasal septum & Conservative excision & Not reported \\
\hline Caltabiano, et al. ${ }^{12)}$ & 31 & M & $\begin{array}{l}\text { Lt diplopia, } \\
\text { photophobia, } \\
\text { exophthalmos }\end{array}$ & Lt frontal sinus & $\begin{array}{l}\text { Endoscopic endonasal } \\
\text { technique with } \\
\text { intraorbital approach }\end{array}$ & Not reported \\
\hline Kiyohara, et al. ${ }^{13)}$ & 14 & $\mathrm{~F}$ & $\begin{array}{l}\text { Rt nasal obstruction, } \\
\text { exophthalmos }\end{array}$ & Rt ethmoid sinus & Complete excision & $\begin{array}{l}\text { No recurrence after } \\
1 \text { year }\end{array}$ \\
\hline Bacot, et al. ${ }^{14)}$ & 12 & $\mathrm{~F}$ & $\begin{array}{l}\text { Rt nasal obstruction, } \\
\text { telecanthus }\end{array}$ & Rt ethmoid sinus & $\begin{array}{l}\text { Surgical resection } \\
\text { after embolization }\end{array}$ & Not reported \\
\hline Vella, et al. ${ }^{15)}$ & 10 & M & Rt exophthalmos & Rt maxillary sinus & Surgical excision & $\begin{array}{l}\text { Recurrence after } \\
8 \text { months }\end{array}$ \\
\hline
\end{tabular}


수의 침범여부를 평가하는 데 도움이 된다."

병리소견은 육아 조직에 출혈이 생긴 것 같은 짙은 적색의 연한 조직이다. 유골과 미성숙골을 형성하는 풍부한 섬유-혈 관 기질이 관찰되고 골 소주와 유골 주위에 한층의 골모세포 가 관찰되는데 이는 골육종과의 감별에 중요하다. 주변 조직 과의 명확한 경계와 경계 내 느슨한 조직 배열은 골모세포종 을 시사하는 또 다른 소견이다. ${ }^{5}$

감별진단으로 유골골종, 골육종, 동맥류성 골낭종 등이 있 다. 특히 유골골종은 골모세포종과 같은 양성 골종양으로서 조직학적으로 유골골종과 유사한 소견을 보이며 같은 종양 의 변종으로 생각되고 있다. 두 종양의 차이는 방사선 소견상 관찰되는 종양핵의 크기로 유골골종은 $1 \mathrm{~cm}$ 이하이고 골모 세포종은 평균 $2 \mathrm{~cm}$ 이상이지만 많은 예에서 유골골종만큼 특징적인 핵이 없다. ${ }^{4)}$ 골육종과는 방사선 소견에서의 차이점 으로 골모세포종은 악성이 걱정되는 정도이지만 골육종은 명 확한 악성의 소견을 보인다. 조직학적 차이는 침습성으로 골 모세포종에서는 병변 주변의 골조직으로 침습성을 나타내지 않는다.

완전한 골 소파술 또는 광범위 절제술이 치료방법이며 필요 시 골 이식술을 시행한다. 소파술 후 $20 \%$ 정도의 재발률을 보이나 완전 절제 후 재발된 경우는 아직 보고된 바가 없다. ${ }^{12)}$ 불완전한 절제 후 남은 병변이 지속적인 문제를 일으키는 경 우가 적어 대부분 방사선 치료는 하지 않는다. 다만 드물게 악성 변화가 보고된 바가 있으므로 골모세포종의 치료 후에 도 발생 부위의 재발 여부와 전이 여부에 대한 지속적인 추적 관찰이 필요하다.

수포성 갑개는 해부학적 변이에 의한 비내갑개의 함기화로 주로 중비갑개에서 발생한다. 보통 증상이 없어 영상학적 검 사에서 우연히 발견되나 함기화의 정도가 심한 경우 비폐색 증 상이 나타나고 두통, 유루증 등이 동반되기도 한다. 함기화 된 갑개 개구부의 폐쇄가 지속되는 경우 국소적인 염증반응 과 점막부종, 부비동염, 저류액 등이 유발될 수 있다. 증상이 없을 경우 치료할 필요가 없고 증상이 있는 경우 수술적 치료 를 시행할 수 있다. ${ }^{2)}$

본 증례는 하비갑개에서 발생한 골모세포종과 이에 대한 수술적 치료 중 동반된 수포성 하비갑개가 발견된 점이 특이
하였다. 비록 드문 경우이지만 본 증례와 같이 소아에서도 약물 치료로 개선되지 않는 비폐색 증상이 있으며 팽창된 하 비갑개 소견을 보인다면, 수포성 하비갑개, 종양성 병변 등의 가능성도 고려하여 빠른 진단을 위해 영상학적 검사 및 병리 조직 검사를 해 볼 필요가 있다고 사료된다.

\section{REFERENCES}

1) Kukwa W, Oziębło A, Oecińska A, Czarnecka AM, Włodarski K, Kukwa A. Aggressive osteoblastoma of the sphenoid bone. Oncol Lett 2010;1(2):367-71.

2) Pittore B, Al Safi W, Jarvis SJ. Concha bullosa of the inferior turbinate: an unusual cause of nasal obstruction. Acta Otorhinolaryngol Ital 2011;31(1):47-9.

3) Jaswal A, Jana AK, Sikder B, Jana U, Nandi TK. Benign osteoblastoma of maxillary sinus: a rare presentation. Indian J Otolaryngol Head Neck Surg 2007;59(1):80-2.

4) Young E, Dabrowski M, Brelsford K. Osteoblastoma of the nasal septum. J Laryngol Otol 2011;125(10):1062-6.

5) Chang YK, Chen PR, Su B, Lee CL. Osteoblastoma of the inferior turbinate. Otolaryngol Head Neck Surg 2011;145(3):517-8.

6) Cekic B, Toslak IE, Yildirim S, Uyar R. Osteoblastoma originating from frontoethmoidal sinus causing personality disorders and superior gaze palsy. Niger J Clin Pract 2016;19(1):153-5.

7) Cikojević D, Colović Z, Lozić B, Klančnik M. Aggressive middle turbinate osteoblastoma with intracranial extension: a case report. J Med Case Rep 2014;8:161.

8) Kim SS, Kim YS, Lee JW, Wee SJ. A case of osteoblastoma arising from the ethmoid sinus. Korean J Otolaryngol-Head Neck Surg 2002; 45(3):296-9.

9) Park YK, Kim EJ, Kim SW. Osteoblastoma of the ethmoid sinus. Skeletal Radiol 2007;36(5):463-7.

10) Sidani CA, Karam AR, Bruce JH, Sklar E. Osteoblastoma of the frontal sinuses presenting with headache and blurred vision: case report and review of the literature. J Radiol Case Rep 2010;4(6):1-7.

11) Kavurt S, Corapcioğu F, Bay S, Ustündağ E, Akansel G, Müezzinoğlu B. A rare tumor of nasal bone in a child: osteoblastoma. Turk J Pediatr 2011;53(2):206-9.

12) Caltabiano R, Serra A, Bonfiglio M, Platania N, Albanese V, Lanzafame $\mathrm{S}$, et al. A rare location of benign osteoblastoma: case study and a review of the literature. Eur Rev Med Pharmacol Sci 2012;16(13): $1891-4$.

13) Kiyohara H, Sawatsubashi M, Matsumoto N, Komune S. Benign osteoblastoma of the ethmoid sinus. Auris Nasus Larynx 2013;40(3): 338-41.

14) Bacot B, Eimer S, Berge J, De Gabory L. Osteoblastoma of the ethmoid sinus. Rev Laryngol Otol Rhinol (Bord) 2013:134(3):161-4.

15) Vella O, Cuny F, Robard L, Bazille C. Osteoblastoma of the maxillary sinus in a child presenting with exophthalmos. Eur Ann Otorhinolaryngol Head Neck Dis 2016;133(4):277-9. 